\title{
Analysis of the Logic Defects of Locke's Claim on Land Privatization
}

\author{
Runian Wang*, Yafei E \\ Department of Marxism, China Pharmaceutical University, Nanjing, China \\ Email: ${ }^{*}$ cpu2019@126.com
}

How to cite this paper: Wang, R. N., \& E Y. F. (2019). Analysis of the Logic Defects of Locke's Claim on Land Privatization. Open Journal of Political Science, 9, 549556.

https://doi.org/10.4236/ojps.2019.93032

Received: June 4, 2019

Accepted: July 16, 2019

Published: July 19, 2019

Copyright $\odot 2019$ by author(s) and Scientific Research Publishing Inc. This work is licensed under the Creative Commons Attribution International License (CC BY 4.0).

http://creativecommons.org/licenses/by/4.0/

(c) (i) Open Access

\begin{abstract}
Property privatization is one of the core contents of Locke's liberalist theory, and Locke's argumentation on the rationality of property privatization begins with the rationality of land privatization. Locke has emphasized the indisputable private nature of labor and its significance in changing the natural state of land in the process of demonstrating the transformation of land from natural state to private state. Meanwhile, Locke has also demonstrated the importance of such transformation for human beings. In this process, Locke implied the theoretical presupposition of human selfishness, and then reasonably defended private ownership. Although Marx has pointed out the evil side of private ownership, few people can logically refute the argumentation of liberal private ownership. This paper sorts out the logical argumentation of Locke's claim on land privatization, and logically analyzes the various possibilities of land ownership after the natural state of land is changed by labor, thus proving this theory's one-sidedness of logic and arbitrariness of choice.
\end{abstract}

\section{Keywords}

Locke, Land Privatization, Logic Defects

\section{Locke’s Claim on Land Privatization}

In the theory of Locke's liberalism, the claim of property privatization is a core component. As for the rationality of property privatization, Locke has demonstrated it based on the rationality of land privatization.

In the chapter of On Property, Locke begins with the right to survive for human beings, and says "God gives things to Adam, Noah and his sons", God "gives the earth to the world", so all people can share it (Locke, 2011a). Then Locke emphasizes that although land and all lower animals are shared by all people, everyone has his own personal right, and no one except himself can have 
this right. It can be said that the work done by a person and his own hands is rightly belonging to this person. So as long as he makes anything be out of its natural state, it means he has changed this thing whit his labor. That is to say, he has added something of his own to this thing, thus making it his own property (Locke, 2011a).

Locke's claim is that anyone who can make an ownerless thing be out of its natural state by his own labor has the ownership of this ownerless thing. Specifically, the laborer puts his labor on the land, and the land becomes his own possession (Locke, 2011a).

We can understand Locke's meaning in this way: in the natural state, the land is basically in a barren state, on which nothing can be grown for human consumption except weeds and sparse trees. Workers have improved the land, either by ploughing, irrigation or fertilization. The land has become suitable for farming due to the improvement of laborers. The condition of the land has been improved, so the land is out of the natural state due to the labor of the laborers. Therefore, this land that has been improved by laborers should belong to the laborers who have been added to it.

Locke has given the following three reasons to demonstrate the rationality of land privatization.

1) As the undisputed possession of the laborer, the labor and its gains can be only enjoyed by the laborer himself. Because this thing's (land's) original state given by the nature has been changed by laborer's working, that is to say, the labor has added something of his own to this thing, thereby denying the common rights of others (Locke, 2011a).

2) Labor can make the land more valuable, meaning that through ploughing and weeding, sowing and harvesting, the land can produce more things needed by human beings. "He has spent his time and energy on the uncultivated land to get the food he needs." (Locke, 2011c) "Manning the land privatization on the basis of a person's working will not decrease, but will increase the common accumulation of human beings." (Locke, 2011d).

3) Before the land becomes private property, there are already facts that people usually collect the ownerless things such as acorns or other fruits to make them private in property. And this seems natural to everyone. These fruits growing in nature can be owned by a person by picking. In a similar way, it is perfectly justified that the land can be privatized based on a person's working (Locke, 2011a).

\section{Logic Defects of Locke's Claim on Land Privatization}

As for Locke's claim on land privatization and the reasons cited, we can find the following problems.

1) Labor is the property of laborers, and land is the common property of all people. It is logical to say that adding the labor of the laborer to the land does change the original form of the land. The laborers can enjoy the harvest obtained from their working (the original crop such as wild fruit shall be deducted from 
the total harvest). However, it is obviously illogical to make the object which belongs to all people become private just because a person has worked on this object. Land in natural state belongs to all people, and the things growing naturally such as wild fruits can be enjoyed by all people. If a person works on a piece of land, this land will become his own. Then no other people can possess this land and enjoy the wild fruits on this land that they could have enjoyed before. Who gives an independent individual the right to deprive others of this right?

2) The reason that labor can improve the state of the land, and through ploughing and weeding, sowing and harvesting, the land can produce more things needed by human beings can only provide us with the necessity of labor. But it does not provide us with the inevitability of the laborer's possession of this land. The labor harvest more from the land by working, but all the gains are owned by the labor himself. For other people, their situation will not be improved, but may become worse. The land is owned by the labor. Therefore, the number of natural fruits that can be relied on by other people is less and less, thus their situation will be even worse.

Locke himself seems to be aware of this defect in this conclusion, so he adds that at least when there are enough good things to share with others, things are like this (Locke, 2011a). Locke means that you can also go to work on a piece of land and therefore have the ownership of this land, because after one person privatizes a piece of land through working, there is still enough land waiting for others to improve.

The question is how to ensure that there are enough good things to give to others.

Nozick has questioned this question in his Anarchy, State and Utopia. Nozick puts forward an example: "A person pours a bottle of ketchup into the sea, and makes it evenly distributed throughout the sea. Then the whole sea is changed, so whether or not the sea belongs to him." (Nozick, 2008). Similarly, no one will think that the person who has opened the perfume bottle and made the fragrance dispersed in the air has the ownership of the air.

In fact, there is no guarantee for this additional item proposed by Locke, whether static or dynamic. Let's take the land mentioned by Locke as an example to develop our hypothesis.

Under static conditions, land is always a limited, and each piece of land is unique. We are not sure how many people there are and whether the land can be distributed to everyone when Locke proposes that the land shall belong to the person who has worked on it. If the population is large enough and the land is not enough, then whether there will be a war between people. After all, territorial disputes occur in the most primitive animals. Locke says that reclaiming the barren land and making it private will not harm other people's interest, because the remaining land of same good quality is far more than the land which can be used by people who have not yet acquired a piece of land (Locke, 2011b). But obviously, there is no proof to prove such case. Even if what Locke said is right, that is, the remaining land is sufficient for those who have not yet acquired a 
piece of land, the land itself still has its location and quality. If I just want to reclaim the same land because of its location and quality, what will happen?

For the land privatization under dynamic conditions, many people have paid attention to it. Many theories have inferred and described the results of land privatization. In the book of On the Principles of Political Economy and Taxation, David Ricardo refers to land as "scarce resources" and thus demonstrates the rationality of increasing land taxation. Although David Ricardo does not discuss the rationality of land privatization, he notices that land has become extremely important because of its scarcity in his time and especially in later times.

Why does land become a "scarce resource"? The simple logic is that the population is constantly increasing, and the expansion of population base speeds up the population growth (Malthus called this geometric growth). But the land area is basically constant. In this case, the contradiction between land and population is highlighted. Some people have enough land, while others have no land. As a result, the situation described by Locke that some people occupy enough land and sufficient good land is still left to the people who have no land will not be realized.

In fact, Locke has further demonstrated that it is reasonable for white people to plunder and take over Native American Indians' land based on the argumentation of improving land to make its use more effective. Although this conclusion is vaguely expressed in Locke's argumentation, it indeed reveals this meaning (Locke, 2011e). According to Locke's logic, it is reasonable for the western society to encroach on and plunder all other less developed areas.

Robert Nozick has made a rigorous inference towards the conditions and problems of occupying the land proposed by Locke. He uses 26 English letters to hypothetically rank the people who might or need to occupy the land. In his inference, there is a person called Z, and there isn't enough and good things left for him to possess. Then $Y$, the last person possessing the thing, deprives $Z$ of his right to enjoy something that he can enjoy before, thus worsening $Z$ 's situation. Therefore, $\mathrm{Y}$ is not allowed to possess the thing under Locke's limited terms. The penultimate person $\mathrm{X}$ who possesses the thing will worsen Y's situation, so $\mathrm{X}$ is not allowed to possess the thing. The antepenultimate person $\mathrm{W}$ who possesses the thing will worsen X's situation, so $\mathrm{W}$ is also not allowed to possess the thing. By parity of reasoning, it can be traced back to the first person A who holds the permanent ownership (Nozick, 2012).

To put Nozick's logical reasoning more bluntly, we can take land as an example: $\mathrm{Z}$, as an individual, has no land on which to add labor, because $\mathrm{Y}$ added labor to the last piece of land. It seems that $\mathrm{Y}$ made $\mathrm{Z}$ lose the same opportunity as other people to work on the land and obtain land ownership. However, $Y$ has no other choice because $\mathrm{X}$ added labor to the penultimate piece of land. By pushing back and forth like this, you will find that starting with the first person A who added labor to the land and then took possession of the land, the opportunities for others are gradually reduced until $\mathrm{Z}$ has no chance. 
Robert Nozick's inference has actually denied the logical rationality of Locke's claim on land privatization, because according to the relevant term proposed by Locke, the first person who makes the land private is not allowed. There is an inherent conflict between Locke's own claim and the term he sets for his claim. Unfortunately, Robert Nozick himself is also a supporter of private ownership, so his argumentation is only to discuss the limits of private property.

3) Locke defends the laborer's ownership of land with the fact that people collect ownerless things like acorn or other fruits to make them private in property. It seems that the possessions of fruits and land are logically consistent, that is, both of them are acquired by working. However, Locke intentionally neglects the attribute differences between ownerless things such as acorns or other fruits and land, which directly led to his failure in logic.

It is well known that acorns or other fruits have obvious timeliness. The ripe fruits will be rotten on the tree if they cannot be timely picked. And as long as the tree is here, it will bear fruit next year. Moreover, it is occasional to meet the fruit, and who can meet the fruit is random. The most fundamental thing is that the ownerless things like acorns or other fruits are renewable. You are lucky to meet and enjoy them this year. While in next year, maybe another person is lucky to meet and enjoy them. Different from acorns or other fruits, land is always there and the most fundamental thing is that it is not nonrenewable. Once it is occupied by someone, other people will be deprived of the right to enjoy the land the original natural things on it. Therefore, we can accept that a person can occupy the fruits picked by himself, but we cannot accept that a person has the right to occupy a piece of land permanently only because once he worked on this land.

\section{Possibility of Land Ownership with Intervene of Labor}

In fact, land is shared by all people under the natural state. With the intervening of labor, its ownership has the following possibilities.

1) The labor can work on the land, but the land is still shared by all people. The harvest gained after the land is improved also belongs to all people. This can increase the overall wealth and improve the overall state of mankind.

The premise for such a possibility is that everyone has the dedication to serve others and regard human beings as a whole. This is a road leading to communist society. Marx once has regarded the great improvement of people's ideological awareness and labor's change to the first need as one of the premises for the realization of communism. Sartori has criticized Marx's theory in his The Theory of Democracy Revisite on the basis of "perfectionism", he affirms that the communism conceived by Marx is just a "Utopia" that could not be realized (Sartori, 2009). However, However, Satoli's criticism on Marx is based on affirming that human beings are selfish and greedy. He also fails to notice that the so-called "nature of selfishness and greed" is actually stimulated by some people's choices of possibilities (such as advocating private ownership) in the course of human existence. Just as Claude Adrien Helvetius, one of the bourgeois Enlightenment 
thinkers in France, once said in his book Mentalistic Theory, "People are not born good or evil, but they are born with the ability to be good or evil, depending on whether the public interest unites them or separates them." "If private benefits cannot be realized until realizing the public welfare, then nobody will commit a crime except madmen." (Helvetius, 1822). As for the opinion that private ownership can induce people's greed, the British thinker St. Thomas More, the French thinker Jean-Jacques Rousseau and the Italian thinker Tommas Campanella have made a quite similar judgment that private ownership is the root of all social evils.

Thomas Robert Malthus has also pointed out in his An Essay on the Principle of Population that the existing property system is the major source of all evils and the hotbed of all crimes that degrade mankind (Malthus, 1992).

2) The labor can work on the land, but the land is still shared by all people. The harvest gained after the land is improved also belongs to the labor.

On the one hand, this will not worsen other people's situation because the laborer improves the land and increases the harvest. After all, the land is not occupied. On the other hand, this will increase the social wealth, thus improving some people's situation. This possibility is provably logical and ethical. As for how to realize it, many technical-level strategies are needed.

3) The labor can work on the land, and both the land and harvest belong to the labor. This will worsen some people's situation while improving some other people's situation.

All the three possibilities possess the undeniable logicality. It's a matter of choice to realize one of them. That is to say, none of them is absolutely inevitable. However, Locke just ignores the other two possibilities and chooses the third one without hesitation. In his opinion, people must be rewarded for their working, otherwise no one will work and the society wealth will not increase. This is because Locke regards human selfishness as an inevitable part of human nature, and in the abundant and uncertain possibilities of human nature, he does not hesitate to regard selfishness and greed as the fundamental nature of human beings. He never thinks about how to restrain and change people's selfishness and greed, but naturally taking it as part of human nature and further inducing and stimulating human selfishness and greed by promoting property ownership.

\section{Conclusion}

Human nature is an extremely complicated and obscure concept. The argument of whether the human nature is good or evil has existed for thousands of years. The individual behaviors in the reality seem to provide us with this judgementpeople are selfish. With that judgement as the basis, Locker made the proposal of land privatization to rectify the private ownership system as a whole. Locker's proposal and theory became a very important political philosophy in the early period of capitalism and a major origin of the liberalism theory.

The private ownership, the validity of which had been proved by the liberalism, became the inner core of the whole capitalist system. Likewise, this core was 
also built upon the same logical starting point, which is the judgement that people are selfish. The introduction of private ownership brought the capitalist system with a series of adaptable social relationships. However, many of these relationships were not so satisfying and a number of philosophers, sociologists and economists like Karl Heinrich Marx, Thomas Robert Malthus, Jean-Jacques Rousseau, Thomas More and Tommas Campanella made drastic criticism and condemnation to the private ownership. Meanwhile, the mass could also feel the guilt and flaw brought by the private ownership. But there was an obvious question: If we deem selfishness as a part of the human nature, in other words human nature is selfish, then the private ownership is impossible to be abolished regardless of how much we hate it given the presumption that human nature cannot be changed.

In reality, some people's behaviors prove the judgement that is completely contradictory to "people are selfish"-people would have the intention to benefit others and the spirit to devote selflessly. For most people, the behavior to benefit others and devote selflessly is inevitable in a certain period. Although this situation is not the evidence for human nature being altruistic and selfless, it subverts the judgement of "people are selfish". In fact, it would be too assertive to define the human nature as being selfish or altruistic. The opinion of Sarte, the essence of human is nihility and the opinion of Helvetius, people are not born to be good or evil, instead they are born to be able to be good or evil, are both proof for the obscurity and variability of the human nature.

The discussion of the good and evil of human nature may be an unceasing issue without a definite result, and that can make us be susceptible to all the conclusions judging the good and evil of human nature. The good and evil of human nature should not be the logical starting point for a system. When we are still universally agreeing the opinion that people's behaviors would be affected by the external environment (which includes the natural environment and humanitarian environment like system), we should think about what kind of environment can guide us to be who we want to be.

No matter the land privatization of Locker varies from the natural state or not, he intentionally chose the private ownership while there are many other options available would without doubt guide the people to be selfish. Although we can't deny the contribution of Locker's theory to fight against the feudalistic ownership and justify the capitalism, that theory would intrigue and encourage the negative intention in the human nature.

This article discusses the logic of Locker's proposal of land privatization in the hope of figuring out the logical flaw of Locker's theory and pointing out the negative impact to the human nature in case of Locker's proposal comes true. Moreover, the article urges for a better system that will intrigue and encourage the good possibility in the human nature and guide the human nature to develop in a positive way. In the future, the human nature (changeable) should be presented in a better manner. 


\section{Conflicts of Interest}

The authors declare no conflicts of interest regarding the publication of this paper.

\section{References}

Helvetius, C. A. (1822). Mentalistic Theory (Paris ed., pp. 339, 369, 169).

Locke, J. (2011a). Two Treatises of Government (p. 117, Translated by Liu, D., Zhao, W.). Changsha: Hunan Literature and Art Publishing House.

Locke, J. (2011b). Two Treatises of Government (p. 119, Translated by Liu, D., Zhao, W.). Changsha: Hunan Literature and Art Publishing House.

Locke, J. (2011c). Two Treatises of Government (p. 120, Translated by Liu, D., Zhao, W.). Changsha: Hunan Literature and Art Publishing House.

Locke, J. (2011d). Two Treatises of Government (p. 121, Translated by Liu, D., Zhao, W.). Changsha: Hunan Literature and Art Publishing House.

Locke, J. (2011e). Two Treatises of Government (p. 123, Translated by Liu, D., Zhao, W.). Changsha: Hunan Literature and Art Publishing House.

Malthus, T. R. (1992). An Essay on the Principle of Population (Chinese Version, p. 69, Translated by Zhu, Y. et al.). Beijing: The Commercial Press.

Nozick, R. (2008). Anarchy, State and Utopia (p. 209, Translated by Yao, D.). Beijing: China Social Sciences Press.

Nozick, R. (2012). Anarchy, State and Utopia (p. 176, Translated by Yao, D.). Beijing: China Social Sciences Press.

Sartori, G. (2009). The Theory of Democracy Revisite (pp. 80-81, Translated by Feng, K., Yan, K.). Shanghai: Shanghai People's Publishing House. 